\title{
Processed foods aimed at children and adolescents: Sodium content, adequacy according to the dietary reference intakes and label compliance ${ }^{1}$
}

Alimentos processados voltados para crianças e adolescentes: concentração de sódio, adequação em relação aos

níveis de ingestão dietética de referência e

conformidade da rotulagem

Vera Favila RIBEIRO2

Marisilda de Almeida RIBEIRO ${ }^{3}$

Margarida Angélica da Silva VASCONCELOS 4

Samara Alvachian Cardoso ANDRADE ${ }^{5}$

Tânia Lúcia Montenegro STAMFORD ${ }^{4}$

A B S T R A C T

\section{Objective}

This study determined the sodium content of processed foods aimed at children and adolescents and the adequacy of its content in relation to the dietary reference intakes, and verified label compliance.

\section{Methods}

The sodium content of 17 food samples (instant noodles, breaded items, hamburger patties, hot dogs and bologna sausages) was determined by flame photometry and chloride titration, and the results were compared with nutritional data. The labels were checked for compliance with the pertinent laws.

${ }^{1}$ Article based on the dissertation of VF RIBEIRO intitled "Alimentos processados para crianças e adolescentes: concentrações de sódio e conformidade da rotulagem". Universidade Federal de Pernambuco; 2011.

2 Universidade Federal de Pernambuco, Centro Acadêmico de Vitória, Núcleo de Nutrição. Av. Prof. Moraes Rego, 1235, Cidade

Universitária, 50670-901, Recife, PE, Brasil. Correspondência para/Correspondence to: VF RIBEIRO. E-mail: <vfavila@hotmail.com>.

3 Universidade Federal de Pernambuco, Departamento de Nutrição. Vitoria de Santo Antão, PE, Brasil.

${ }^{4}$ Universidade Federal de Pernambuco, Centro de Ciências da Saúde, Departamento de Nutrição. Recife, PE, Brasil.

${ }^{5}$ Universidade Federal de Pernambuco, Centro de Tecnologia, Departamento de Engenharia Química. Recife, PE, Brasil. 
398 | VF RIBEIRO et al.

\section{Results}

According to flame photometry and chloride titration, 13 and 5 products, respectively, had sodium contents that exceeded those reported on the nutrition facts label by more than $20 \%$. All samples had more than $480 \mathrm{mg}$ of sodium per serving. The tolerable upper intake level for sodium for children aged 4-8 years was exceeded in 8 instant noodles and 3 breaded items according to flame photometry, and in 9 items according to chloride titration. Regarding the legislation, 5 products used a daily reference intake other than that provided by the legislation to report their percent sodium content per serving. Moreover, the serving sizes of 3 instant noodles, the terminology used in 1 instant noodles and the protein content of 1 breaded item were also not compliant with the legislation.

\section{Conclusion}

The sodium contents in the study samples were high and there was no regard for the legislation.

Indexing terms: Food labeling. Processed foods. Sodium chloride.

\section{RE S U M O}

\section{Objetivo}

Determinar o teor de sódio em alimentos processados voltados para crianças e adolescentes, averiguar a adequação do teor encontrado em relação aos níveis de ingestão dietética de referência e verificar a conformidade das informações veiculadas na rotulagem.

\section{Métodos}

Análise experimental do teor de sódio em 17 amostras (massa instantânea, empanado, hambúrguer, salsicha e mortadela) pela fotometria de chama e determinação de cloretos por volumetria. Os resultados foram comparados aos dados das informações nutricionais. A conformidade da rotulagem foi verificada a partir das legislações pertinentes.

\section{Resultados}

Houve variação maior que 20\% entre o teor de sódio analisado e o declarado em 13 produtos pela fotometria de chama, e em 5, pela volumetria. Todas as amostras apresentaram mais de $480 \mathrm{mg}$ de sódio/porção e o limite de ingestão adequada para crianças de 4 a 8 anos foi ultrapassado, pela fotometria, nas 8 massas instantâneas e em 3 empanados. Pela volumetria, a oferta de sódio ultrapassa os níveis de ingestão recomendados para crianças entre 4 e 8 anos em 9 amostras analisadas. Em relação à legislação: 5 amostras apresentaram desacordos nos percentuais de referência estabelecidos; a regulamentação das porções dos alimentos foi descumprida por 3 massas instantâneas; 1 produto dessa categoria utilizou-se de denominação incorreta; e 1 empanado apresenta teor proteico menor que o estabelecido.

\section{Conclusão}

Verificou-se elevado teor de sódio nos alimentos e desrespeito às legislações vigentes.

Termos de indexação: Rotulagem de alimentos. Alimentos processados. Cloreto de sódio.

\section{NTRODUCTION}

In the last decades, the consumption of processed foods such as instant noodles, hot dogs, bologna sausage, hamburger patties and breaded items has increased, mainly because of their fast preparation and affordability. Their taste, obtained with food ingredients and additives, is also appealing to most consumers who use them in place of or along with the main meals, especially meals for children and adolescents.
In order to meet the demand for these products, the food industry offers the convenience desired by adults and attractive packaging for the youth. However, the addition of sodium to processed foods should be monitored, justifying the required nutrition facts label.

The increasing consumption of processed foods along with the addition of salt during cooking and at the table are the main causes of the excessive sodium intake of the Brazilian 
population ${ }^{1,2}$. Consequently, the Ministry of Health presented a Plan for Fighting Chronic Non-communicable Diseases (CNCD), which includes actions to promote healthy diets and includes a goal to reduce the mean salt consumption of $12 \mathrm{~g}$ to $5 \mathrm{~g}$ by $2022^{3}$.

In order to reach these goals, Ministry of Health and many food industry associations began signing agreements in 2011 to reduce the sodium content of many foods, such as instant noodles, breads, cakes, corn chips, potato chips, mayonnaise, sweet and savory cookies, breakfast cereals and seasonings ${ }^{4}$.

These government actions are very important, but since the nutrient content reported on the label can stem from chemical analyses or calculations based on product formulation ${ }^{5}$, and since the Brazilian legislation allows the contents reported on the label and those determined analytically to differ by as much as $20 \%^{6}$, it is important to check the accuracy of the reported data.

In addition to the nutrition facts label and other compulsory information, each product has particularities that must comply with various resolutions and normative instructions, and the packaging is the consumer's information source. Therefore, it is essential to verify if the legislation is being followed.

The objectives of this study were to determine the sodium content of processed foods whose packaging aims at children and adolescents, verify if their sodium contents are in agreement with the daily reference intakes and verify if the information on the label is in conformity with the legislation.

\section{METHODS}

The study food items were chosen based on Agência Nacional de Vigilância Sanitária's (Anvisa, National Sanitary Surveillance Agency) Technical Communication $n^{\circ}$ 42/20107, which contains the nutritional profile of some processed foods with high sodium, saturated fat and sugar contents that are usually consumed by the Brazilian population. The inclusion criteria were the possibility of using the food to replace or complement a meal, and the presence of elements on the packaging that appealed to children and adolescents.

Seventeen food items were analyzed, namely eight instant noodles from three different brands, one hamburger patty, one bologna sausage, two hot dogs from two different brands and five breaded items from three different brands.

Once the samples were acquired, the nutrition facts labels were recorded in a form created for this purpose and compared with the resolutions provided by the executive board of directors of Anvisa ${ }^{6,8-10}$ and with the normative instructions provided by the Ministério da Agricultura e Pecuária (Ministry of Agriculture, Livestock and Supply) ${ }^{11-13}$.

The raw samples were ground and homogenized by a food processor for approximately 90 seconds. The seasonings of the noodle samples were homogenized together with the noodles. An aliquot of $5 \mathrm{~g}$ of each sample was placed in a porcelain capsule previously desiccated and weighed by an analytical scale of the brand Sartorius BL2105. The samples were burned by a Bunsen burner until no more smoke was emitted.

The ashes were obtained as recommended by the Association of Official Analytical Chemists ${ }^{14}$ (AOAC). Sodium content was quantified by flame photometry as recommended by the $\mathrm{AOAC}^{15}$ and the chloride in sodium chloride was quantified by the method 028/IV of Institute Adolfo Lutz ${ }^{16}$, where the sodium content is estimated to be $40 \%$ of the amount of chloride found.

These quantitative techniques were chosen because of the high sodium contents normally found in processed foods and because chloride titration and sodium quantification by flame photometry are official methods used by the Anvisa.

In order to verify the adequacy of the sodium content, the sodium content per serving reported on the label and that determined 
400 | VF RIBEIRO et al.

analytically were compared with the Adequate Intake (Al) values for children and adolescents aged 4-8 and 9-18 years and with the tolerable Upper Intake Levels (UL) for children and adolescents aged 4-8, 9-13 and 14-18 years ${ }^{17}$.

The experimental results were submitted to Analysis of Variance (Anova) and compared by the Duncan test, using a probability level of $5 \%$. The statistical treatment was done by the software Statistica for Windows 7.0".

\section{RE S U L T S}

Table 1 shows the food characteristics and marketing strategies present on the labels and the reported sodium contents of the 17 study foods.

The label contents of 5 of the 17 study products did not comply with the legislation, violating norms RDC $n^{\circ} 360 / 3^{6}, \operatorname{RDC} n^{\circ} 359 / 3^{10}$, RDC $n^{\circ} 263 / 5^{8}$ and IN n०6/1 ${ }^{11}$.
The labels of all study products were in compliance with the legislation regarding the listing of nutrients and respective percentages of their daily requirements. However, 5 did not use the established daily reference intakes. The nutrition facts label of the study hamburger patty reported a sodium content of $629 \mathrm{mg}$ of sodium per serving, which, according to the said label, corresponds to $13 \%$ of the daily reference intake. However, if the considered daily reference intake is $2,400 \mathrm{mg}$ of sodium ${ }^{6}$, the reported amount corresponds to $26 \%$ of the daily reference intake.

Three instant noodles also used daily reference intakes different from those provided by the legislation. The percentages of proteins and vitamins $B_{1}, B_{2}, B_{3}$ and $B_{6}$ in the instant noodles $D$ and $E$ refer to the requirements of children aged 7-10 years, while the percentages of the same vitamins in the instant noodles $\mathrm{H}$ refer to the requirements of children aged 4 to 6 years. The other nutrients use the daily intake references provided by the resolution ${ }^{6}$.

Table 1. Characteristics, marketing strategies present on the packaging and sodium contents of ready-to-eat and fast foods aimed at children and adolescents. Recife (PE), Brazil, 2011.

\begin{tabular}{|c|c|c|c|c|c|c|c|c|c|}
\hline \multirow[b]{2}{*}{ Product } & \multicolumn{2}{|c|}{ Characteristics } & \multicolumn{4}{|c|}{ Marketing strategies } & \multicolumn{3}{|c|}{ Sodium content (mg/100g) } \\
\hline & Flavor & Shape & $\begin{array}{c}\text { TV } \\
\text { character }\end{array}$ & $\begin{array}{c}\text { Colorful } \\
\text { letters }\end{array}$ & Games & Other ${ }^{*}$ & Label & Flame photometry & Titration \\
\hline InsNood A & Beef & Standard & Yes & Yes & No & Yes & $2351.75^{a}$ & $2556.71^{a}$ & $1896.18^{a}$ \\
\hline InsNood B & Chicken & Standard & Yes & Yes & No & Yes & $2310.59^{a}$ & $2184.99^{a}$ & $2166.94^{a}$ \\
\hline InsNood C & Tomato & Standard & Yes & Yes & No & Yes & $2014.12^{b}$ & $2771.96^{a}$ & $1722.81^{b}$ \\
\hline InsNood D & Beef & Standard & Yes & Yes & No & Yes & $2387.50^{a}$ & $2532.96^{\mathbf{a}}$ & $1786.95^{\mathrm{b}}$ \\
\hline InsNood E & Chicken & Standard & Yes & Yes & No & Yes & $2384.40^{a}$ & $2801.98^{a}$ & $2007.05^{a}$ \\
\hline InsNood F & Mild beef & Standard & No & Yes & No & Yes & $1642.30^{\mathbf{b}}$ & $2301.78^{a}$ & $1702.29^{b}$ \\
\hline InsNood G & Mild chicken & Standard & No & Yes & No & Yes & $1990.60^{\mathbf{b}}$ & $2776.31^{a}$ & $1781.91^{b}$ \\
\hline InsNood H & Beef & Standard & Yes & Yes & No & Yes & $2133.00^{\mathrm{ab}}$ & $2574.95^{a}$ & $1786.63^{b}$ \\
\hline Brltem A & Chicken & Standard & Yes & No & Yes & Yes & $400.00^{c}$ & $980.21^{a}$ & $778.03^{b}$ \\
\hline Brltem B & Chicken & Varied & Yes & Yes & Yes & Yes & $400.00^{c}$ & $927.37^{a}$ & $633.56^{b}$ \\
\hline Brltem C & Chicken w/carrot & Standard & Yes & No & Yes & Yes & $400.00^{b}$ & $899.57^{a}$ & $810.02^{a}$ \\
\hline Brltem D & Fish & Seafood & No & Yes & No & Yes & $453.00^{c}$ & $847.73^{a}$ & $665.29^{b}$ \\
\hline Brltem E & Chicken & Stars & No & No & No & Yes & $708.00^{\mathbf{b}}$ & $1448.31^{a}$ & $1264.60^{a}$ \\
\hline HPatty A & Chicken & Standard & Yes & No & Yes & Yes & $786.00^{b}$ & $1094.99^{a}$ & $861.41^{b}$ \\
\hline Hot $\operatorname{dog} A$ & Chicken & Standard & Yes & No & No & Yes & $1180.00^{b}$ & $1685.28^{a}$ & $1261.44^{b}$ \\
\hline Hot dog B & Chicken & Miniature & No & Yes & No & Yes & $936.00^{\mathbf{b}}$ & $1553.69^{a}$ & $881.27^{b}$ \\
\hline BolSau A & Chicken & Standard & Yes & No & No & Yes & $1180.00^{\mathbf{b}}$ & $2009.75^{a}$ & $1246.81^{b}$ \\
\hline
\end{tabular}

Note: InsNood: Instant Noodles; Brltem: Breaded Items; HPatty: Hamburger Patty; BolSau Bologna Sausage.

Measurements in the same line followed by same letters are not significantly different at the $5 \%$ significance level according to the Duncan test. *Made especially for children and adolescents; mild flavor; consumption should accompany decorated dishes to encourage children to eat; information about sites with games; drawings of characters, animals or mascots on the packaging; information encouraging children to practice physical activities; easy and fast to prepare; contains vitamins and other nutrients. 
Companies may include other nutrients on the nutrition facts label if they exceed $5 \%$ of the Daily Reference Intake (DRI) ${ }^{6}$ per the serving size indicated on the label. The breaded item $D$ incorrectly reports calcium. Its content of $23.0 \mathrm{mg}$ per serving corresponds to only $2 \%$ of the DRI, not $5 \%$, which would be equivalent to $57.5 \mathrm{mg}$.

The serving sizes reported on the labels of three instant noodles did not comply with the serving size of this type of food provided by the legislation, which is of $80 \mathrm{~g}$. The packaging of the instant noodle $\mathrm{H}$ contained $80 \mathrm{~g}$ of product, but the reported serving size was $33 \mathrm{~g}$, and the reported nutrient contents were for this serving size. On the other hand, the packaging of the instant noodles $D$ and $E$ did not contain $80 \mathrm{~g}$ but $64 \mathrm{~g}$, that is, less than the amount required by the legislation ${ }^{10}$.
The technical norms for the denomination of grain and starchy products, flours and brans ${ }^{8}$ were also violated. The instant noodle $\mathrm{H}$ consisted of wheat flour and cassava starch and called itself instant noodle. However, according to the legislation, noodles are made exclusively from wheat flour and/or durum wheat derivatives. When another source of starch is added, the product is classified as a dough mix.

The identity and quality standard for breaded products requires a minimum protein content of $10 \%{ }^{11}$. The breaded item D had $22.0 \mathrm{~g}$ of protein, representing a protein content of $9 \%$. Therefore, it was not in compliance with the law, since it should contain at least $24.4 \mathrm{~g}$ of protein.

Figure 1 shows that the difference between the reported and quantified sodium

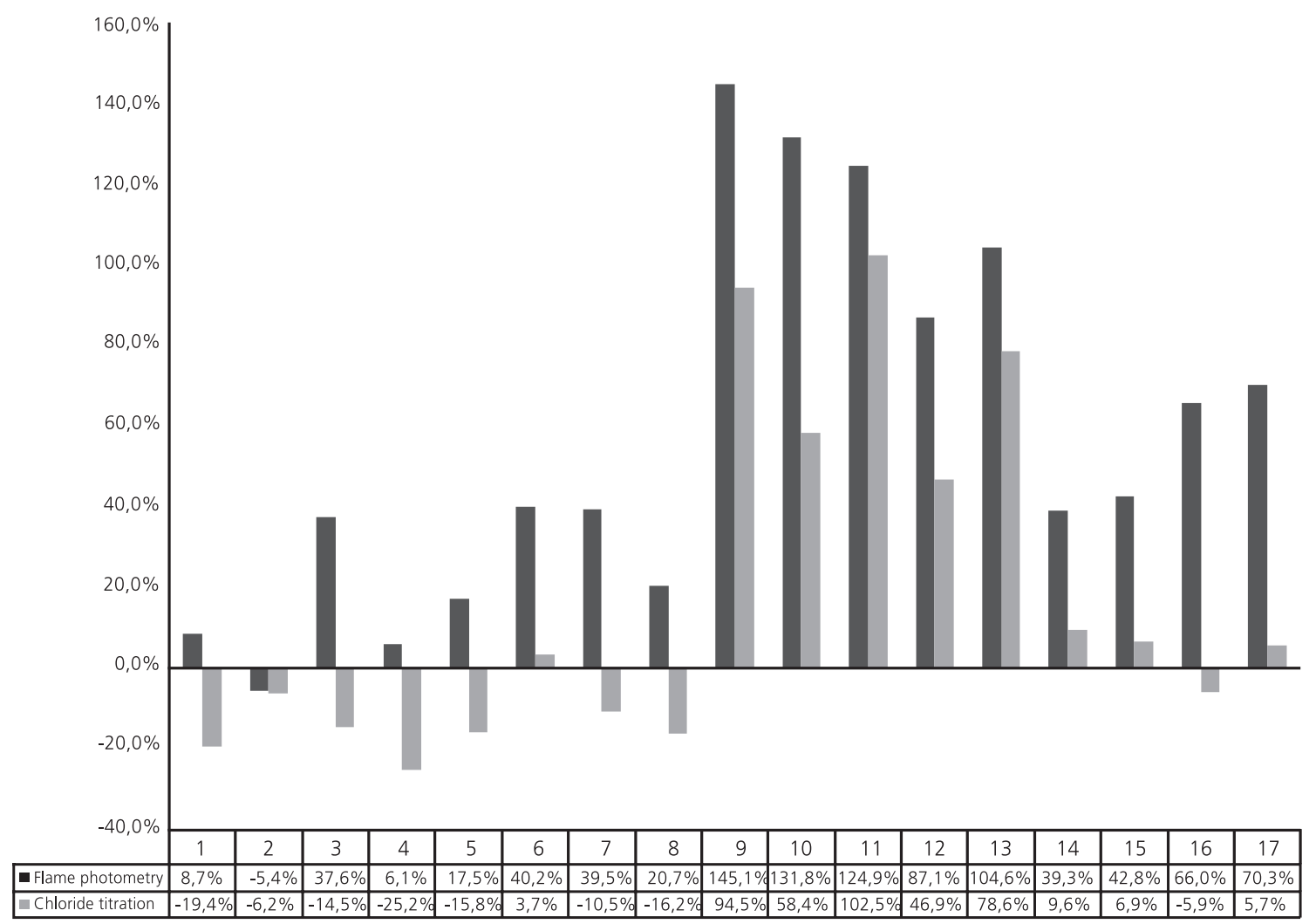

Figure 1. Percentage variation between the sodium contents reported on the labels and those found analytically by flame photometry and titration. Recife (PE), Brazil, 2011

Note: 1: Instant noodles A; 2: Instant noodles B; 3: Instant noodles C; 4: Instant noodles D; 5: Instant noodles E; 6: Instant noodles F; 7: Instant noodles G; 8: Instant noodles H; 9: Breaded item A; 10: Breaded item B; 11: Breaded item C; 12: Breaded item D; 13: Breaded item E; 14: Hamburguer patty $A ; 15$ : Hot $\operatorname{dog} A ; 16: \operatorname{Hot} \operatorname{dog} B ; 17$ : Bol sausage $A$. 
contents exceeded $20 \%$ in 13 products analyzed by flame photometry and 5 analyzed by chloride titration. Therefore, these products are not in compliance with the norm RDC 360/036.

Based on flame photometry, all 17 samples are high in sodium since all of them have more than $480 \mathrm{mg}$ of sodium per serving ${ }^{18}$. Eight instant noodle samples and three breaded items analyzed by flame photometry exceeded the UL for sodium for children aged 4-8 years. Additionally, all 17 study products had sodium contents in excess of $50 \%$ of the UL for all age groups. Finally, the UL for sodium for children aged 4-8 years was exceeded by six instant noodle samples (Table 2).

Table 3 compares the sodium contents per serving determined by chloride titration with the sodium DRI for children and adolescents. According to this method, only hot dog B was not classified as a high-sodium food ${ }^{18}$. The sodium contents of 9 study products exceeded the UL for children aged $4-8$ years and all 8 instant noodles provided more than $50 \%$ of the UL for all age groups.
DISCUSSION

Since the nutritional data reported by the food industry can be determined by chemical analyses and calculations based on the formulation of the product ${ }^{5}$, nutrient contents may differ. These different methods may partially explain the difference between the contents reported on the label and those found analytically by the present study, which, according to the legislation, should not exceed $20 \%{ }^{6}$.

Thirteen samples analyzed by flame photometry and 5 by chloride titration exceeded the tolerated difference (Figure 1). Other studies found differences in sodium contents in excess of $20 \%$ in $5(50 \%)$ pastas $^{19}$ and 64 (57\%) snack and potato chips $^{20}$, corroborating the results of the present study. These excessive differences show that it is essential to effectively survey all nutrition information reported on the labels to check their accuracy, allowing well-informed

Table 2. Comparison between the sodium content according to flame photometry and the daily reference intakes ${ }^{\mathrm{a}}$ for children and adolescents. Recife (PE), Brazil, 2011.

\begin{tabular}{|c|c|c|c|c|c|c|}
\hline \multirow{2}{*}{ Product } & \multirow{2}{*}{$\mathrm{Na}(\mathrm{mg}) /$ serving $^{\mathbf{b}}$} & \multicolumn{2}{|c|}{$\%$ Al adequacy/serving } & \multicolumn{3}{|c|}{$\%$ UL adequacy/serving } \\
\hline & & $4-8$ years $^{c}$ & $9-18$ years $^{d}$ & $4-8$ years $^{\mathrm{e}}$ & $9-13$ years $^{f}$ & $14-18$ years $^{9}$ \\
\hline InsNood A & 2045.37 & 170.4 & 136.4 & 107.6 & 92.9 & 88.9 \\
\hline InsNood B & 1747.99 & 145.7 & 116.5 & 92.0 & 79.4 & 76.0 \\
\hline InsNood C & 2217.57 & 184.8 & 147.8 & 116.7 & 100.8 & 96.4 \\
\hline InsNood D & 2026.37 & 168.9 & 135.1 & 196.7 & 92.1 & 88.1 \\
\hline InsNood E & 2241.58 & 186.8 & 149.4 & 117.9 & 101.9 & 97.5 \\
\hline InsNood F & 1841.42 & 153.4 & 122.8 & 96.9 & 83.7 & 80.1 \\
\hline InsNood G & 2221.05 & 185.1 & 148.1 & 116.9 & 100.9 & 96.6 \\
\hline InsNood H & 2059.96 & 171.7 & 137.3 & 108.4 & 93.6 & 89.6 \\
\hline Brltem A & 1274.27 & 106.2 & 84.9 & 67.1 & 57.9 & 55.4 \\
\hline Brltem B & 1205.58 & 100.5 & 80.4 & 63.4 & 54.8 & 52.4 \\
\hline Brltem C & 1169.44 & 97.4 & 78.0 & 61.5 & 53.1 & 50.8 \\
\hline Brltem D & 1102.05 & 91.8 & 73.5 & 58.0 & 50.1 & 47.9 \\
\hline Brltem E & 1882.80 & 156.9 & 125.5 & 99.1 & 85.6 & 81.9 \\
\hline HPatty A & 875.99 & 73.0 & 58.4 & 46.1 & 39.8 & 38.1 \\
\hline Hot dog A & 842.64 & 70.2 & 56.2 & 44.3 & 38.3 & 36.6 \\
\hline Hot dog B & 776.85 & 64.7 & 51.8 & 40.9 & 35.3 & 33.8 \\
\hline BolSau A & 803.90 & 67.0 & 53.6 & 42.3 & 36.5 & 34.9 \\
\hline
\end{tabular}

Note: InsNood: Instant Noodles; Brltem: Breaded Items; HPatty: Hamburger Patty; BolSau: Bologna Sausage; Al: Appropriate Intake; UL: Upper Intake Level.

${ }^{a} F o o d$ and Nutrition Board/National Research Council (2004). bServing sizes according to the norm RDC n 359/2003: Hamburger patty=80g; Breaded item=130g; Instant noodles=80g; Bologna sausage=40g; Hot dog=50g. ${ }^{\mathrm{C}} \mathrm{Al}: 1.2 \mathrm{~g} /$ day. ${ }^{\mathrm{d}} \mathrm{Al}: 1.5 \mathrm{~g} / \mathrm{day}$. ${ }^{\mathrm{e}} \mathrm{UL}$ : $1.9 \mathrm{~g} / \mathrm{day}$. ${ }^{\mathrm{f} U L}$ : $2.2 \mathrm{~g} / \mathrm{day}$. gUL: $2.3 \mathrm{~g} /$ day. 
Table 3. Comparison between the sodium content according to chloride titration and the daily reference intakes ${ }^{\mathrm{a}}$ for children and adolescents. Recife (PE), Brazil, 2011

\begin{tabular}{|c|c|c|c|c|c|c|}
\hline \multirow{2}{*}{ Product } & \multirow{2}{*}{$\mathrm{Na}(\mathrm{mg}) /$ serving $^{\mathbf{b}}$} & \multicolumn{2}{|c|}{$\%$ Al adequacy/serving } & \multicolumn{3}{|c|}{$\%$ UL adequacy/serving } \\
\hline & & $4-8$ years $^{c}$ & $9-18$ years $^{d}$ & $4-8$ years $^{\mathbf{e}}$ & $9-13$ years $^{f}$ & $14-18$ years $^{9}$ \\
\hline InsNood A & 1516,94 & 126,4 & 101,1 & 79,8 & 68,9 & 65,9 \\
\hline InsNood B & 1733,55 & 144,5 & 115,6 & 91,2 & 78,8 & 75,4 \\
\hline InsNood C & 1378,25 & 114,8 & 91,9 & 72,5 & 62,6 & 59,9 \\
\hline InsNood D & 1429,56 & 119,1 & 95,3 & 75,2 & 64,9 & 62,1 \\
\hline InsNood E & 1605,64 & 133,8 & 107,0 & 84,5 & 72,9 & 69,8 \\
\hline InsNood F & 1361,83 & 113,5 & 92,1 & 71,7 & 61,9 & 59,2 \\
\hline InsNood G & 1425,53 & 118,8 & 95,0 & 75,0 & 64,8 & 61,9 \\
\hline InsNood H & 1429,30 & 119,1 & 95,3 & 75,2 & 64,9 & 62,1 \\
\hline Brltem A & 1011,44 & 84,3 & 67,4 & 53,2 & 45,9 & 43,9 \\
\hline Brltem B & 823,63 & 68,6 & 54,9 & 43,3 & 37,4 & 35,8 \\
\hline Brltem C & 1053,03 & 87,8 & 70,2 & 55,4 & 47,9 & 45,8 \\
\hline Brltem D & 864,88 & 72,1 & 57,6 & 45,5 & 39,3 & 37,6 \\
\hline Brltem E & 1643,98 & 136,9 & 109,6 & 86,5 & 74,7 & 71,5 \\
\hline HPatty A & 689,13 & 57,4 & 45,9 & 36,3 & 31,3 & 29,9 \\
\hline Hot dog A & 630,72 & 52,6 & 42,0 & 33,2 & 28,7 & 27,4 \\
\hline Hot dog B & 440,64 & 36,7 & 29,4 & 23,2 & 20,0 & 19,1 \\
\hline Bolsau A & 498,72 & 41,6 & 33,2 & 26,2 & 22,7 & 21,7 \\
\hline
\end{tabular}

Note: InsNood: Instant Noodles; Brltem: Breaded Items; HPatty: Hamburger Patty; BolSau: Bologna Sausage; Al: Appropriate Intake; UL: Upper Intake Limit.

aFood and Nutrition Board/National Research Council (2004). bServing sizes according to the norm RDC $n^{\circ}$ 359/2003 ${ }^{10}$ : Hamburger patty=80g; Breaded item=130g; Instant noodles=80g; Bologna sausage=40g; Hot dog=50g. ${ }^{\mathrm{c} A l:} 1.2 \mathrm{~g} / \mathrm{day}$. ${ }^{\mathrm{d} A \mathrm{Al}} 1.5 \mathrm{~g} / \mathrm{day}$. ${ }^{\mathrm{e} U L:}$ 1.9g/day. ${ }^{\mathrm{f} U L:} 2.2 \mathrm{~g} / \mathrm{day}$ gUL: $2.3 \mathrm{~g} /$ day.

Table 4. Variation of the sodium content of same-category foods. Recife (PE), Brazil 2011.

\begin{tabular}{|c|c|c|c|}
\hline Product & Mean ${ }^{\mathbf{a}} \mathrm{Na}(\mathrm{mg}) /$ serving $^{\mathbf{b}}$ & $\begin{array}{l}\text { Difference between the maximum and minimum } \\
\text { contents found ( } \mathrm{n}^{\circ} \text { of times) }\end{array}$ & Country \\
\hline Instant noodles & 2721 & 2,25 & \multirow{4}{*}{ Brazilc } \\
\hline Breaded chicken & 759 & 1,86 & \\
\hline Poultry hamburger patty & 525 & 2,6 & \\
\hline Hot dog & 551 & 2,0 & \\
\hline Instant noodles & 413 & 14,5 & \multirow{3}{*}{ Austráliad } \\
\hline Hamburger patty & 384 & 19,0 & \\
\hline Hot dog & 412 & 9,4 & \\
\hline Breaded chicken & 407 & 2,1 & \multirow{3}{*}{ New Zealand } \\
\hline Hamburger patty & 368 & 1,9 & \\
\hline Hot dog & 426 & 1,9 & \\
\hline Instant noodles & 2178 & 1,3 & \multirow{3}{*}{ Brazil $^{f}$} \\
\hline Breaded chicken and fish & 1326 & 1,7 & \\
\hline Chicken hot dog & 809 & 1,5 & \\
\hline Instant noodles & 1528,3 & 1,5 & \multirow{3}{*}{ Brazilg } \\
\hline Beef hamburger patty & 560,8 & 8,4 & \\
\hline Chicken bologna sausage & 492,8 & 1,6 & \\
\hline
\end{tabular}

Note: aMean contents found by flame photometry; bInstant noodles: 85g; Breaded items: 130g; Hamburger patty: 80g; Hot dog: 50g; Bologna

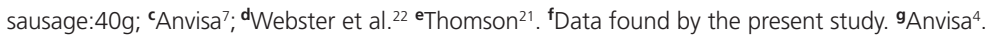


consumers to correctly choose the most appropriate food item among all those available.

Comparison of the sodium contents reported on the labels with those determined analytically shows that the differences between both are significant $(p<0.05)$ in 12 samples analyzed by flame photometry and 6 samples analyzed by chloride titration. Many factors may influence the results of the chemical analyses, such product formulation and analytical method. The determination of chlorides by titration assesses salinity ${ }^{16}$ while flame photometry determines the content of sodium ions directly ${ }^{15}$. This may explain the differences between the contents found by this study.

Table 4 shows that the mean sodium contents of same-category foods vary widely, which is confirmed by the literature ${ }^{21,22}$ and Anvisa ${ }^{4,23}$. This study used the means obtained by flame photometry, which is more accurate. The variations seen in same-category foods show that it is possible to produce foods with lower sodium contents without affecting the technology used for their production $4,7,24$.

Foods with colorful packaging and popular characters, drawings and games attract the young public and indicate to adults that they are meant for children. However, this is not the case since the mean sodium contents of these products quantified by this study are higher than those found in similar products by Anvisa ${ }^{4,7}$.

Moreover, Table 2 shows that, according to flame photometry, all study products contained more than $480 \mathrm{mg}$ of sodium per serving, so they are considered high-sodium foods ${ }^{18}$. It is also noteworthy that the serving sizes are not necessarily equal to the consumed portion sizes and the meal may have other high-sodium foods, elevating sodium ingestion and significantly contributing to an excessive sodium intake by children and adolescents.

Given the high intake of processed foods by children and adolescents ${ }^{25-28}$, the replacement of meals by snacks $s^{24,29}$ and the high sodium contents of the study foods, one can infer that they contribute to a high sodium intake.
The existence of foods that provide as much as $100 \%$ of the UL for sodium, such as some instant noodles, shows that sodium content exceeds reasonable parameters and, as intake exceeds the UL, the associated health hazards also increase ${ }^{30}$.

The risk factors for CNCD are widespread in society. People are often exposed to them early and/or during most of their lifetime ${ }^{3}$. A study assessed the introduction of processed foods to infants in public daycare centers of São Paulo and found that instant noodles are offered to $77.8 \%$ of the children aged 12 months or less ${ }^{31}$. Another recent study with 1,131 students aged 7 to 14 years found a prevalence of pre-hypertension of $9.6 \%$ and of hypertension of $4.8 \%$; the prevalences were greater in females, individuals with excess weight and individuals with inappropriate diets ${ }^{32}$.

Since the consumption of processed foods by children and adolescents increases because of women working outside the home, greater convenience, quick preparation, durability and acceptance $^{26}$, peer influence, higher purchase power, habit of eating out ${ }^{27}$, and advertising and marketing 25,28 , asking the food industry to reduce sodium content of their products is considered more effective than asking people to reduce the consumption of these products ${ }^{33}$.

This reduction in the sodium content of processed foods will be achieved according to the goals established by the $\mathrm{MH}$ and the food industry for the coming years. However, given the differences between the reported and quantified sodium contents, monitoring will be necessary to ensure industry compliance with these goals. This agreement, along with other health-promoting actions, will greatly contribute to the prevention and reduction of CNCD, including hypertension ${ }^{3}$.

Since some study products were not in compliance with the legislation, better surveillance is necessary. Given that the pertinent laws have been around for a number of years, it is unacceptable that packaging still contains misleading and incorrect information, that products do not comply with the defined identity and amount, and that compulsory nutrition 
information is manipulated to become one more marketing strategy.

The technical regulation that establishes the minimum requirements for the supply, marketing, advertising, information and other correlated practices that aim to market foods with high sugar, saturated fat, trans fat and sodium contents, and beverages with low nutrient contents, do not apply to food labeling ${ }^{23}$, so this important marketing vehicle continues to be available to the food industry.

\section{CONCLUSION}

The results show that the study foods contain high sodium contents that must be reduced. The government's goal to reduce sodium intake and its partnership with the food industry to reduce the sodium content of many foods are essential initiatives but not enough. Encouraging the consumption of fresh foods and providing effective education measures are critical for the promotion of healthy eating habits and minimization of the prevalence of CNDC.

\section{CONTRIBUTORS}

VF RIBEIRO responsible for data collection and analysis and article writing. MA RIBEIRO responsible for project creation and article review. MAS VASCONCELOS responsible for reviewing data analysis and the article. SAC ANDRADE responsible for the statistical analysis of the data. TLM STAMFORD COresponsible for project creation and article review.

\section{REFERENCES}

1. Brasil. Ministério da Saúde. Guia alimentar para a população brasileira: promovendo a alimentação saudável. Brasília: MS; 2005.

2. Sarno F, Claro RM, Lezy RB, Bandoni DH, Ferreira SRG, Monteiro CA. Estimativa de consumo de sódio pela população brasileira, 2002-2003. Rev Saúde Pública. 2009; 43(2):219-25. doi: 101590/s0034-8 9102009005000002.

3. Malta DC, Neto OLM, Junior JBS. Apresentação do plano de ações estratégicas para o enfrentamento das doenças crônicas não transmissíveis no Brasil,
2011 a 2022. Epidemiol Serv Saúde. 2011; 20(4): 425-38. doi: 10.5113/S1679-49742011000400 002.

4. Brasil. Agência Nacional de Vigilância Sanitária. Informe Técnico n 50/2012. Teor de sódio dos alimentos processados. Brasília: Anvisa; 2012.

5. Brasil. Agência Nacional de Vigilância Sanitária. Rotulagem nutricional obrigatória: manual de orientação às indústrias de alimentos - $2^{\circ}$ versão. Brasília: Anvisa; 2005 [acesso 2010 mar 18]. Disponível em: <http://www.anvisa.gov.br/rotulo/manual_ industria.pdf>.

6. Brasil. Agência Nacional de Vigilância Sanitária. Resolução RDC n 360, de 23 de dezembro de 2003. Aprova o regulamento técnico sobre rotulagem nutricional de alimentos embalados, tornando obrigatória a rotulagem nutricional. Diário Oficial da União. 200323 dez.

7. Brasil. Agência Nacional de Vigilância Sanitária. Informe Técnico $n^{\circ}$ 42/2010. Perfil nutricional de alimentos processados. Brasília: Anvisa; 2010.

8. Brasil. Agência Nacional de Vigilância Sanitária. Resolução RDC n²63, de 22 de setembro de 2005. Aprova o regulamento técnico para produtos de cereais, amidos, farinhas e farelos. Diário Oficial da União. 200523 set.

9. Brasil. Agência Nacional de Vigilância Sanitária. Resolução RDC n²59, de 20 de setembro de 2002. Aprova o regulamento técnico sobre rotulagem de alimentos embalados. Diário Oficial da União. 2002 23 set.

10. Brasil. Agência Nacional de Vigilância Sanitária. Resolução RDC n 359, de 23 de dezembro de 2003. Aprova o regulamento técnico de porções de alimentos embalados para fins de rotulagem nutricional. Diário Oficial da União. 200326 dez.

11. Brasil. Ministério da Agricultura e Pecuária. Instrução normativa $n^{\circ}$ 6, de 15 de fevereiro de 2001. Aprova os regulamentos técnicos de identidade e qualidade de paleta cozida, produtos cárneos salgados, empanados, presunto tipo serrano e prato elaborado pronto ou semipronto contendo produtos de origem animal. Anexo III: regulamento técnico de identidade e qualidade de empanados. Diário Oficial da União. 200119 fev.

12. Brasil. Ministério da Agricultura e Pecuária. Instrução normativa $n^{\circ}$ 4, de 31 de março de 2000. Aprova os regulamentos técnicos de identidade e qualidade de carne mecanicamente separada, de mortadela, de lingüiça e de salsicha. Anexos II e IV: regulamentos técnicos de identidade e qualidade de mortadela e salsicha. Diário Oficial da União. 20005 abr.

13. Brasil. Ministério da Agricultura e Pecuária. Instrução normativa $n^{\circ} 20$, de 31 de julho de 2000. Aprova os regulamentos técnicos de identidade e quali- 
406 | VF RIBEIRO et al.

dade de almôndega, de apresuntado, de fiambre, de hamburguer, de kibe, de presunto cozido e de presunto. Anexo IV: regulamento técnico de identidade e qualidade de hamburguer. Diário Oficial da União. 20003 ago.

14. Association of Official Analytical Chemists. Methods of analysis. 16 ${ }^{\text {th }}$ ed. Gaitherburg: AOAC; 1997.

15. Association of Official Analytical Chemists. Official methods of Analysis of AOAC International. 15 th ed. Arlington: AOAC; 1990.

16. Zenebon O, Pascuet NS, Coordenadores. Métodos físico-químicos para análise de alimentos. $4^{\mathrm{a}}$ ed. São Paulo: Instituto Adolfo Lutz; 2005.

17. Food and Nutrition Board. National Research Council. Dietary reference intakes for water, potassium, sodium, chloride, and sulfate. Washington (DC): The National Academics Press; 2004 [cited 2010 Mar 1]. Available from <http:// www.nap.edu>.

18. Brasil. Agência Nacional de Vigilância Sanitária. Rotulagem nutricional obrigatória: manual de orientação aos consumidores. Educação para o consumo saudável. Brasília: Anvisa; 2001 [acesso 2010 mar 5]. Disponível em: <http://www.anvisa. gov.br/alimentos/rotulos/manual_rotulagem.pdf>.

19. Sauerbronn ALA. Análise laboratorial da composição de alimentos processados como contribuição ao estudo da rotulagem nutricional obrigatória de alimentos e bebidas embalados no Brasil [dissertação]. Rio de Janeiro: Fiocruz; 2003.

20. Lobanco CM, Vedovato GM, Cano CB, Bastos DHM. Fidedignidade de rótulos de alimentos comercializados no município de São Paulo, SP. Rev Saúde Pública. 2009; 43(3):499-505. doi: 10.1590/ S003489102009005000020.

21. Thomson BM. Nutritional modelling: Distribuitions of salt intake from processed foods en New Zealand. Br J Nutr. 2009; 102(5):757-65. doi: 10.1017/S00 0711450928901X.

22. Webster JL, Dunford EK, Neal BC. A systematic survey of the sodium contents of processed foods. Am J Clin Nutr. 2010; 91:413-20. doi: 10.3945/ajen 2009.28688.

23. Brasil. Agência Nacional de Vigilância Sanitária. Resolução RDC n² 24, de 15 de junho de 2010. Regulamento técnico que estabelece os requisitos mínimos para oferta, propaganda, publicidade, informação e outras práticas correlatas cujo objetivo seja a divulgação e a promoção comercial de alimentos considerados com quantidades elevadas e de açúcar, de gordura saturada, de gordura trans, de sódio e de bebidas com baixo teor nutricional. Diário Oficial da União. 201029 jun. Seção 1. [acesso 2010 set 8]. Disponível em: <http://portal.anvisa. gov.br>.
24. Almeida SS, Nascimento PCBD, Quaioti TCB. Quantidade e qualidade de produtos alimentícios anunciados na televisão brasileira. Rev Saúde Pública, 2002; 36(3):353-5. doi: 10.1590/S0034-891 02002000300016.

25. Aquino RC, Philippi ST. Consumo infantil de alimentos industrializados e renda familiar na cidade de São Paulo. Rev Saúde Pública. 2002; 36(6):655-60. doi: 10.1590/S0034-89102002000700001.

26. Filho EAR, Vier BP, Campos E, Günther LA, Carolino IR. Avaliação nutricional de um grupo de adolescentes. Acta Sci Health Sci. 2005; 27(1):63-7.

27. Godoy FC, Andrade SC, Morimoto JM, Carandina L, Goldbaum M, Barros MBA, et al. Índice de qualidade da dieta de adolescentes residentes no distrito de Butatã, Município de São Paulo, Brasil. Rev Nutr. 2006; 19(6):663-71. doi: 10.1590/S1415-5273200 6000600003.

28. Pontes TE, Costa TF, Marum ABRF, Brasil ALD, Taddei JAAC. Orientação nutricional de crianças e adolescentes e os novos padrões de consumo: propagandas, embalagens e rótulos. Rev Paul Pediatr. 2009; 27(1):99-105. doi: 10.1590/S0103-0582200 9000100015.

29. Vargas ICS, Sichieri R, Sandre-Pereira, G, Veiga GV. Avaliação de programa de prevenção de obesidade em adolescentes de escolas públicas. Rev Saúde Pública. 2011; 45(1):59-68. doi: 10.1590/50034-8 9102011000100007.

30. Marchioni DML, Slater B, Fisberg RM. Aplicação das dietary reference intakes na avaliação da ingestão dietética de nutrientes. Rev Nutr. 2004; 17(2): 207-16. doi: 10.1590/S1415-52732004000200 007.

31. Toloni MHA, Longo-Silva G, Goulart RMM, Taddei JAAC. Introdução de alimentos industrializados e de alimentos de uso tradicional de crianças de creches públicas no município de São Paulo. Rev Nutr. 2011; 24(1):61-70. doi: 10.1590/S1415-5273 2011000100006.

32. Pinto SL, Silva RCR, Priore SE, Assis AMO, Pinto EJ. Prevalência de pré-hipertensão e de hipertensão arterial e avaliação de fatores associados em crianças e adolescentes de escolas públicas de Salvador-Bahia-Brasil. Cad Saúde Pública. 2011; 27(6):1065-76. doi: 10.1590/S0102-311X201100 0600004.

33. Dötsch M, Busch J, Batenburg M, Liem C, Tareilus E, Mueller R, et al. Strategies to reduce sodium consumption: A food industry perspective. Crit Rev Food Sci Nutr. 2009; 49(10):841-51. doi: 10.1080/10 408390903044297. 